
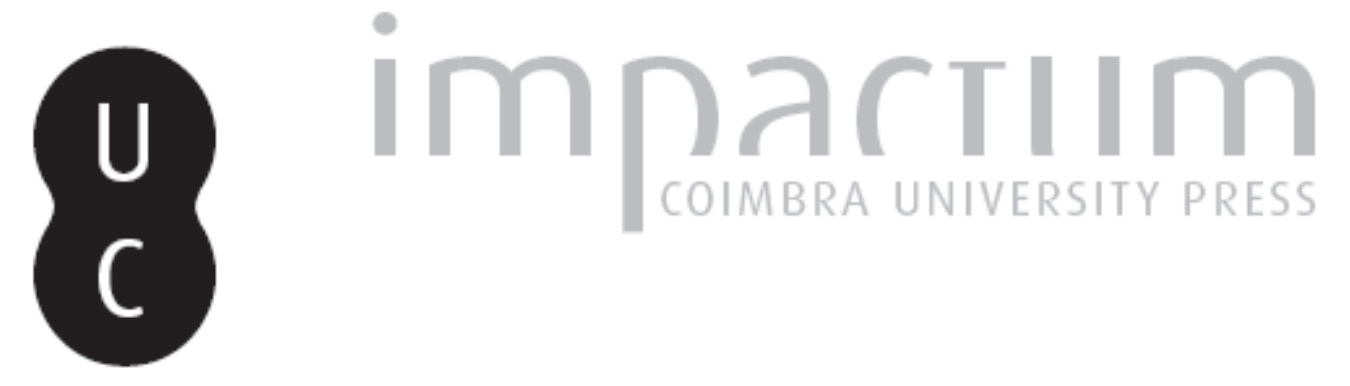

\title{
Apollonius and the Golden Fleece: a neo-mythological screen legacy
}

Autor(es): Winkler, Martin M.

Publicado por: Imprensa da Universidade de Coimbra

URL persistente:

URI:http://hdl.handle.net/10316.2/43399

DOI:

DOI:https://doi.org/10.14195/1984-249X_22_13

Accessed : $\quad$ 26-Apr-2023 11:55:33

A navegação consulta e descarregamento dos títulos inseridos nas Bibliotecas Digitais UC Digitalis, UC Pombalina e UC Impactum, pressupõem a aceitação plena e sem reservas dos Termos e Condições de Uso destas Bibliotecas Digitais, disponíveis em https://digitalis.uc.pt/pt-pt/termos.

Conforme exposto nos referidos Termos e Condições de Uso, o descarregamento de títulos de acesso restrito requer uma licença válida de autorização devendo o utilizador aceder ao(s) documento(s) a partir de um endereço de IP da instituição detentora da supramencionada licença.

Ao utilizador é apenas permitido o descarregamento para uso pessoal, pelo que o emprego do(s) título(s) descarregado(s) para outro fim, designadamente comercial, carece de autorização do respetivo autor ou editor da obra.

Na medida em que todas as obras da UC Digitalis se encontram protegidas pelo Código do Direito de Autor e Direitos Conexos e demais legislação aplicável, toda a cópia, parcial ou total, deste documento, nos casos em que é legalmente admitida, deverá conter ou fazer-se acompanhar por este aviso.

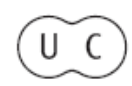




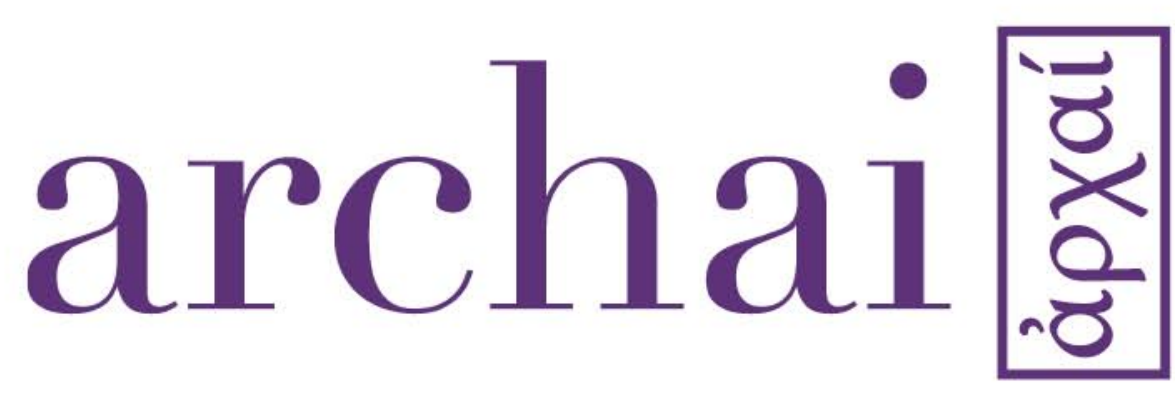

Revista sobre as origens do pensamento ocidental Journal on the Origins of Western Thought

22 | Jan.-Apr. 2018 


\section{Apollonius AND THE Golden FLEECE: A NEO-MYTHOLOGICAL SCREEN LEGACY}

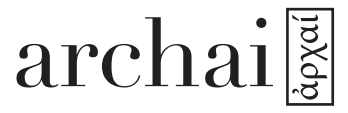

no 22, Jan.-Apr. 2018
WINKLER, M. M. (2018). Apollonius and the Golden Fleece: A neo-mythological screen legacy. Archai, n. ${ }^{\circ}$ 22, Jan.-Apr., p. 319-362 DOI: https://doi.org/10.14195/1984-249X_22_13

Abstract: A number of ancient poets and painters described or showed the Golden Fleece, one of the most intriguing supernatural objects in classical myth. But the poets were not as specific as their modern readers may wish. By contrast, cinema and television show the Fleece in all its specific aspects. Moving-image adaptations of classical myths always change their sources, a phenomenon usefully termed "neo-mythologism," but they display the Fleece to good effect, if often in a variety of recreations. The seven European and American films examined here show us why the Fleece deserves the Homeric epithet thauma idesthai.

Keywords: Golden Fleece, Apollonius, Jason, Medea, films. 


\section{archai 䀥}

$n^{\circ}$ 22, Jan.-Apr. 2018

Martin M. Winkler, 'Apollonius and the Golden Fleece: A neomythological screen legacy', p. 319-362
Among all the supernatural objects found in classical mythology, the Golden Fleece may be the most famous and influential in inspiring poets, dramatists, and painters since antiquity. The Fleece is the reason for an arduous journey to Colchis, a kingdom at the ends of the earth. A golden-fleeced ram had once saved Phrixus and his twin sister Helle from the machinations of their evil stepmother by carrying them east. The ram's father was Poseidon in animal shape; its mother, a nymph temporarily in animal shape as well, was a granddaughter of the sun god Helius. In the best-known version of the myth, the ram had wings and could talk. Either its fleece was naturally golden, or Hermes had made it so. (On this Fränkel, 1968, p. 293-294.) Helle fell off the ram's back and drowned in the Hellespont, the sea named after her. The ram then gave verbal encouragement to Phrixus and took him to Colchis, where it was sacrificed. Its fleece became a symbol of power, royalty, and authority. It was kept in a tree inside a grove sacred to Ares. Colchian King Aeëtes kept the Fleece in his possession. In the bestknown versions it was guarded by a dragon. (A concise recent summary of the myth and its variants is in Boyle, 2014, p. lxi-lxxviii, with references.) According to Diodorus Siculus 4. 48. 3, the never-sleeping dragon was coiled around the Fleece. Such a version would look particularly arresting on screen but has never been filmed. Diodorus tells the whole myth at 4. 40-55.

In Greece, evil Pelias had killed his brother Aeson, the legitimate ruler of the Thessalian kingdom of Iolcus, and usurped his throne. When Aeson's son Jason came to reclaim the kingdom that was rightfully his, Pelias sent his nephew to obtain the Golden Fleece for 
him. To undertake his dangerous task, Jason gathered about fifty heroes and sailed to Colchis. Jason's companions were called Argonauts after their ship, the Argo. But King Aeëtes would not willingly relinquish his greatest possession and imposed deadly tests upon Jason. The Argonauts' quest was thus meant to be a mission impossible: Pelias intended to get rid of Jason and keep the throne; Jason and the Argonauts were never to return. But with the help of Aeëtes' daughter Medea, who possessed magic powers and was in love with Jason, the best of the Argonauts succeeded. He got the Fleece-in some versions Medea got it for him - he got the girl, and he got back home. But Jason and Medea did not get to live happily ever after.

\section{The Golden Fleece in Apollonius' Argonautica}

What did the Golden Fleece look like? We may be able to imagine the golden look of a ram's fleece, but is that enough to impress on us, or on ancient Greeks and Romans, a sense of its inherent or symbolic value? The Fleece has to be supernaturally beautiful to function in a credible manner as the object of a quest as dangerous as the Argonauts' and remarkable enough to deserve being called a thauma idesthai: "a wonder to behold." This expression is Homer's and occurs several times in the Iliad and Odyssey. Hom. Il. 5. 725 is its first occurrence. Ancient visual artists depicted the Fleece on several occasions, but they could not do justice to its golden sheen. ${ }^{1}$ Nor, apparently, could poets. Classical descriptions of the Fleece are too brief adequately to convey a sense of its beauty; they consist mainly of summary statements or assertions. A case in point is Apollonius of Rhodes, whose Argonautica

\section{$\operatorname{archai}$ 苃}

no 22, Jan.-Apr. 2018

Martin M. Winkler, 'Apollonius and the Golden Fleece: A neomythological screen legacy', p. 319-362 


\section{archai圈}

no 22, Jan.-Apr. 2018

Martin M. Winkler, 'Apollonius and the Golden Fleece: A neomythological screen legacy', p. 319-362 is the most detailed retelling of the myth about Jason and the Fleece in classical epic. Apollonius was not only a poet but also a literary scholar; he may also have been the head of the famous Library of Alexandria in Egypt, one of the greatest centers of learning in the Hellenistic Age.

Apollonius does not have all that much to say about the appearance of the Fleece, as if its extraordinary quality defied him. The ram was "that wondrous creature, all gold." In the Ram's Rest, a meadow in Ares' grove, stood "that vast oak on which the Fleece / was spread out, just like some cloud that blushes ruddy gold, / caught by the fiery rays of the sun at its rising." Once Medea has put the dragon to sleep, Jason takes down the Fleece, which is as large as an ox hide. And "the bright glint of its texture / cast a ruddy blush like a flame." Its thick wool is "golden throughout." And: "Brightly the earth / gleamed ever in front of his feet as he strode on forward." Jason's men "were amazed" at "the great Fleece gleaming / like Zeus's lightning." Later, Jason and Medea spread "the bright Golden Fleece" on their marriage bed: "A glow like firelight shone round them, / so bright the light that glittered from the Fleece's golden tufts." ${ }^{5}$ Apollonius echoes the archaic poet Pindar, who centuries earlier had Pelias speak of "the deep-fleeced hide of the ram" and had Aeëtes call it "the imperishable coverlet, / the fleece fringed with gleaming gold." Pindar then speaks of "the shimmering fleece." ${ }^{\circ}$

What do we learn from all this? The Fleece, Peter Green states, looked "a deep metallic red-gold" so strong that it illuminated its environs (Green, 2007, p. 40). The imperial Roman poet Valerius Flaccus, in 
his epic retelling of the myth, spoke of "the sheepskin's golden cloud that shines with the dazzle of Iris' / glowing robe."7 All this leaves us wanting to know more specifically what this magical object was like. We may be reminded of Virgil's expression non enarrabile textum about the shield of Aeneas: the "texture" which Hephaestus, the divine craftsman, imparts to the images decorating the shield "cannot be told" (Virg. Aen. 8. 625 [clipei non enarrabile textum] and 626-728). Green comments on the Fleece: "Perhaps most remarkably, the Fleece...remains a complete (and highly numinous) mystery....We are not even told what generates its unearthly magical glow" (Green, 2007, p. 40). He draws this inevitable conclusion:

Ap. betrays a certain confusion in these lines regarding the exact nature of the Fleece: not altogether surprisingly, since several conflicting versions were known. The scholiast ([on lines] 176-177) reports it variously described as golden, white, or purple. Cf. schol. 114648 , where again the two main versions have it gold (the majority opinion, seemingly) or dyed sea-purple....Even if we treat it as a purely imaginary literary artifact, there is an elusive aspect to Ap.s presentation: his Fleece is singularly hard to visualize. ${ }^{8}$

A dissenting opinion, however, has recently been advanced. Richard Hunter remarks on Apollonius' two lines devoted to the Fleece's extraordinary size:

the very precision of the specification of size, combined with a focus, not just on the Fleece as a whole, but on the individual clumps of wool (175), creates a powerful ecphrastic effect. Even readers who are puzzled by the

\section{archai圈}

no 22, Jan.-Apr. 2018

Martin M. Winkler, 'Apollonius and the Golden Fleece: A neomythological screen legacy', p. 319-362 


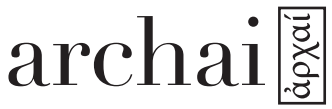

no 22, Jan.-Apr. 2018

Martin M. Winkler, 'Apollonius and the Golden Fleece: A neomythological screen legacy', p. 319-362 glosses of 174-5 are pushed towards a very precise image of this extraordinary (mythical) artefact. (HUNTER, 2015, p. 105, on Argon. 4. 174-175)

Whether readers of Apollonius remain puzzled or are capable of a precise image, one thing becomes evident: all are called upon to use their powers of imagination to visualize the Fleece. To adduce Virgil's expression again: whether something is enarrabile in a poetic textum or not, it certainly is imaginabile. Readers themselves create the wondrous object in their mind's eye, thus making it thauma idesthai.

Today, a modern medium takes things even further. A supernatural object becomes literally visibile when placed before our actual eyes. That medium is the cinema (and its offspring, television). On the screen, each and every object, whether realistic or imaginary, must become visible in all its specificities.

\section{Classical Mythology and Cinematic NeO-Mythologism}

To date, seven films, all in color, have shown the Fleece to good effect. On the following pages, the different imaginative approaches to the visibile textum of the Fleece taken by the filmmakers will be examined through a critical and descriptive explication des textes filmiques, as it were. Five of these filmic texts are examples of mainstream commercial cinema; two of them come from the age of computer technology. The remaining two are examples of art cinema. All are revealing about the ways in which filmmakers present us with modern versions of a classic tale. 
One specific aspect deserves our attention first. It pertains directly to our films' storylines and their visual recreations of the Golden Fleece. Adaptations of narrative literature in other media are rarely faithful to their sources. This is practically always the case with the cinema. Italian writer-director Vittorio Cottafavi, who made two noteworthy films about Hercules, referred to this phenomenon as "neo-mythologism." This is not a modern phenomenon. Given the great flexibility inherent in the oral and literary traditions of ancient myth, Greeks and Romans could themselves be highly neo-mythological. Numerous different and often contradictory versions of myths attest to this.

A distinguished filmmaker provides us with a useful perspective. Animator Ray Harryhausen once observed about his approach to, and experience with, Greek myth:

There are few other sources where you could find so many adventures, bizarre creatures and larger-than-life heroes....However, we soon realized that the storylines needed some modification if we were to translate them to the cinema screen....Sometimes we may have played a bit fast and loose with the plots, or introduced creatures from one story into another, but that is the great thing about those tales: you can keep to the spirit of the original without slavishly following it....I suspect that the ancient Greeks would have been pleased with what we did-even if the academics have not always been quite so impressed. (HARRYHAUSEN and DALTON, 2005/2006, p. 99)

Harryhausen is unlikely ever to have heard the term neo-mythologism, but his statement in defense of what Cottafavi had in mind is as eloquent as it is

\section{archai蒡}

no 22, Jan.-Apr. 2018

Martin M. Winkler, 'Apollonius and the Golden Fleece: A neomythological screen legacy', p. 319-362 


\section{archai圈}

no 22, Jan.-Apr. 2018

Martin M. Winkler, 'Apollonius and the Golden Fleece: A neomythological screen legacy', p. 319-362 sensible. Harryhausen's words apply to all the films examined here.

\section{HeRCULES (1958)}

Italian writer-director Pietro Francisci chose American bodybuilder Steve Reeves to play the titular hero in Le fatiche di Ercole ("The Labors of Hercules," 1958). The film became an international success, especially when savvy American producer and distributor Joseph E. Levine launched it in the United States under the simplified title Hercules. The original title might lead us to expect that the film illustrates Heracles' famous twelve labors. But these labors are only a loose string of adventures, so Francisci and his co-writers introduced a clever change. Although they incorporated some, although not all, of the labors, their storyline includes Jason and the Argonauts. Heracles had been one of the Argonauts in the myth but left their expedition before they reached Colchis. In this way, the greatest of all Greek heroes did not overshadow Jason, the Argonauts' leader and a lesser hero. A title card in the film's opening credits explicitly acknowledges Apollonius' epic as main source. This is the only time Apollonius has received such a screen credit. The card is honest enough to admit that everything has, of course, been treated freely (Fig. 1). ${ }^{10}$ There is, for instance, no Medea.

The sequence in which the Fleece is found is a bit of a disappointment although by no means a failure. For one thing, Jason and not the hero whose film this is kills the dragon and gets the Fleece. And the sequence is not conceived or filmed and edited very imaginatively. Having just landed in Colchis, the Argonauts 


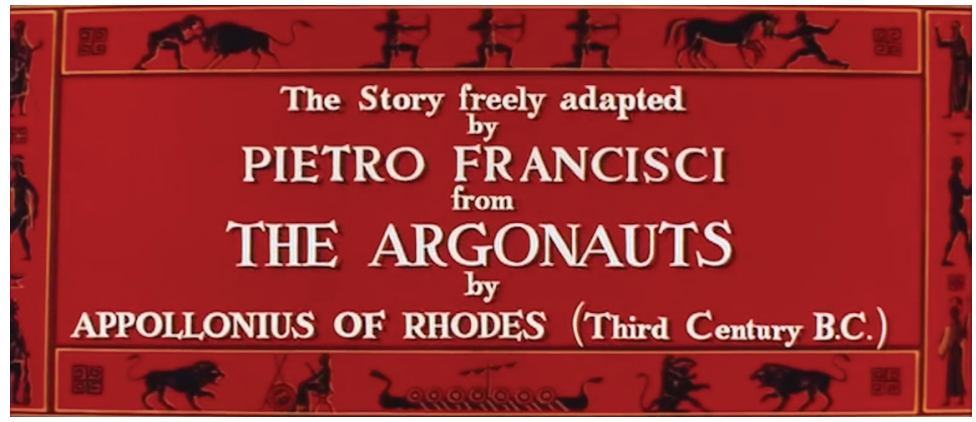

Fig. 1

are being attacked by non-mythical savages who look like humanoid apes from prehistory. When these monsters flee, Jason is suddenly missing. A cut shows us a deserted rocky landscape; another cut reveals the tree with the Golden Fleece in extreme long shot. Dead leaves cover a mound of earth below the tree. Jason now sees the Fleece, and Francisci gives us a closer look (Fig. 2). The Fleece is not overly large, and its golden color appears subdued except for the ram's bright golden horns. Head and horns move a little in the breeze; this makes for an eerie effect. The music heightens the mystery and suspense. Jason walks up the mound and stretches out his arms to take down the Fleece. Suddenly the ground he stands on begins to move, and he tumbles down. The mound rises - it is the dragon! And it is huge. In close-up or medium shot it looks impressively menacing, although in long shots it appears rather silly because of its disproportionately tiny head. Francisci stages Jason's fight with the dragon as if this were a medieval epic. Jason, for instance, is caught and cast aside by the dragon's whipping tail more than once. But he manages to dispatch the beast with a single spear throw into its eye.

\section{archai圈}

no 22, Jan.-Apr. 2018

Martin M. Winkler, 'Apollonius and the Golden Fleece: A neomythological screen legacy', p. 319-362 


\section{$\operatorname{archai}$}

no 22, Jan.-Apr. 2018

Martin M. Winkler, 'Apollonius and the Golden Fleece: A neomythological screen legacy', p. 319-362

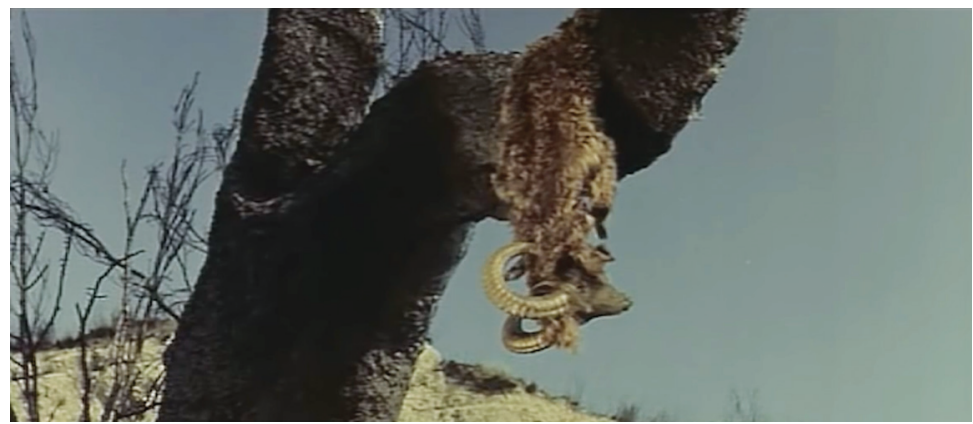

Fig. 2

He looks up at the Fleece again, which receives another close-up. Jason climbs onto the dead dragon's back. (So he does in Val. Flacc. Argon. 8. 109-114, following Medea's advice.) He pulls down the Fleece and runs off to join the Argonauts. But first he takes a closer look at the Fleece and discovers that there are large bloodstains on the inside. There is also a message written in blood. In voice-over we are told what it says:

My brother killed me. Pelias' are the hands that struck me as I slept. May the gods forgive him for what he did, but may they persecute and curse him if he harms my son. I commit Jason into your hands, o gods, and I ask of you to free his thoughts from revenge, for no more blood must be shed because of my death.

This is a noble speech, accompanied on the soundtrack by a female choir delivering a kind of wordless warbling hymn. But it is improbably long to have been composed by a dying man. And it is unmythical. Still, viewers are by no means perplexed by Aeson's final words because they already know what 


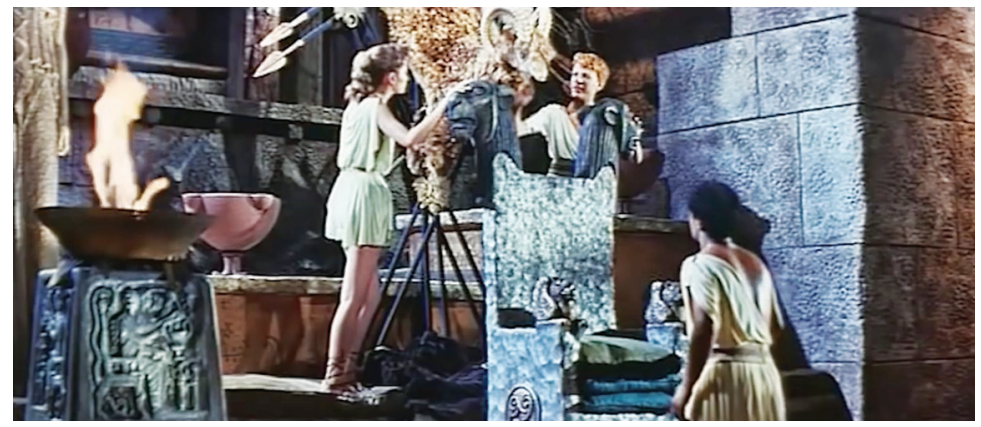

Fig. 3

no ancient Greek or Roman knew: that the Fleece had originally belonged to Aeson. In an expository flashback early in the film, Francisci had shown the Fleece prominently displayed behind Aeson's throne, stretched out on a frame formed by spears (Fig. 3). The Fleece, Hercules is informed, was considered " $a$ royal symbol," which "seemed to give off a mysterious presence; it seemed to vibrate." "You know," Hercules is further told, "reigning without the Golden Fleece is almost impossible." So the Fleece had been in Iolcus all along, and the story of Phrixus and Helle is quietly erased. The Fleece vanishes during the night of Aeson's assassination, which made Pelias king. The killer is Eurystheus, an evil schemer and assassin who later will be one of the Argonauts. Although the name is taken from the Heracles myth, everything else about this Eurystheus is invented. He finally gets what he deserves from Hercules. The Fleece had vanished from Iolcus when Jason's teacher Chiron, who here is not a centaur but fully human, had secretly taken it to prevent it from falling into Pelias' hands. Justice is eventually restored, and Pelias commits suicide. But first he burns the Fleece. This is entirely neo-mythological.

\section{archai圈}

no 22, Jan.-Apr. 2018

Martin M. Winkler, 'Apollonius and the Golden Fleece: A neomythological screen legacy', p. 319-362 


\section{archai圈}

no 22, Jan.-Apr. 2018
Martin M. Winkler, 'Apollonius and the Golden Fleece: A neomythological screen legacy', p. 319-362
Pindar, for instance, had called the Fleece "imperishable" (Pyth. 4. 230).

\section{The Giants of Thessaly (1960)}

A sequel to Francisci's film appeared a year later. Francisci and Reeves started a whole cycle of pseudomythical muscleman epics. Jason and the Argonauts returned in 1960, if without Hercules.

Director Riccardo Freda's film has two titles. It is commonly known as I giganti della Tessaglia (The Giants of Thessaly) but was also called Gli Argonauti ("The Argonauts"). Apollonius is never acknowledged. The story is only loosely based on ancient sources. Freda, too, once broke a lance for neo-mythologism although he did not employ the term:

The chief difficulty...is to tell something exceptional in a believable and acceptable manner....So for this reason it's much more difficult to make a costume film than a modern film-more difficult and more interesting.... The difficulty is to render plausible and close to ourselves characters who proceed in very different costumes, in an altogether strange décor. So it is necessary to reach the point to give them a way of saying and doing things that would at the same time be suitable to our own sensibilities and to these decorative elements. ${ }^{11}$

Freda's version of the Argonauts' story is comparable in its inventiveness to what Francisci and his writers had concocted although it is somewhat simpler. Jason is king of Iolcus and has a family. The narrator informs us that the Fleece is a sacred gift from Zeus and a sign of his favor. But it vanishes, and the people 
are faced with imminent destruction from volcanic eruptions. These are Zeus' punishment for the loss of the Fleece. Jason and the Argonauts set out for Colchis to appease the god and prevent the worst. During his absence, an evil schemer plots to take over as king. He also has designs on Jason's wife.

The setting in which Jason finds the Fleece is bold in its visual presentation and surprising to anyone familiar with the myth. While the Argonauts wait on their ship, Jason climbs up a rocky cliff and a steep stone wall. He then opens a large gate and looks up. Freda cuts to a long shot of a huge stone statue of a kind of kouros standing in front of a wall and inside a large pool of water. The statue's right hand, palm up, is at its shoulder and holding the Golden Fleece. Columns topped by flames indicate that this is a temple or sanctuary. The grove of Ares thus becomes a man-made space. There is no dragon. But there are also no priests, attendants, or guardians, just as there are no Colchians and no Aeëtes. That there is no Medea does not surprise us, for we know that Jason is already married.

In a cleverly designed composition, Freda frames Jason's and our first view of this place with mighty pillars screen left and right, thus lending a greater sense of three-dimensional depth to his image (Fig. 4). Dramatic music underscores the uncanny setting. So, very soon, will some small reddish clouds wafting before the back wall and across the statue's top. They look fake but enhance the supernatural atmosphere of the scene.

Jason, amazed, looks at the statue's hand, which appears in an extreme close-up. A close-up on its palm

\section{archai蒡}

no 22, Jan.-Apr. 2018

Martin M. Winkler, 'Apollonius and the Golden Fleece: A neomythological screen legacy', p. 319-362 


\section{archai圈}

no 22, Jan.-Apr. 2018

Martin M. Winkler, 'Apollonius and the Golden Fleece: A neomythological screen legacy', p. 319-362

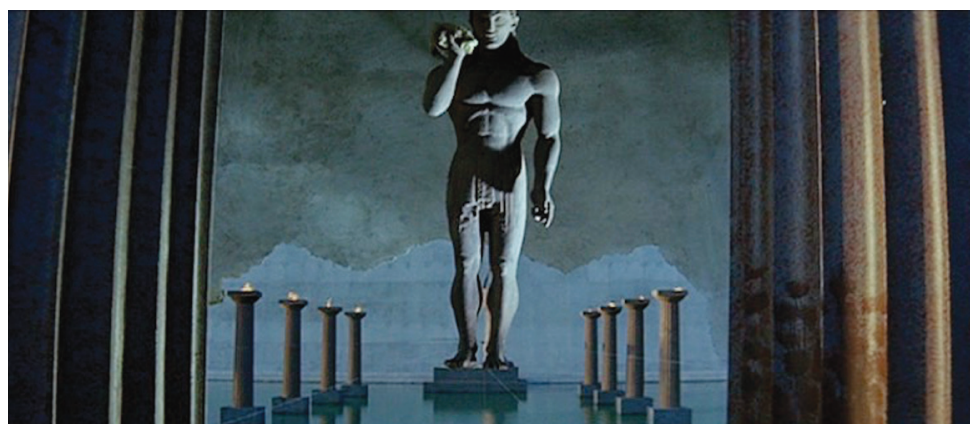

Fig. 4

reveals the Fleece screen left, balanced screen right by part of the statue's face. The Fleece is rather large, and its locks are gently wafting in the air. Jason approaches, his footsteps dramatically resounding through the empty space. He swims across the pool - more echoing sound effects - and climbs onto one of the statue's feet. Suddenly he seems to be outdoors. The mismatch shows experienced viewers that what had come before was filmed separately and that the statue, when we get a full view of it, is a miniature. Hacking footholds into the stone, Jason climbs to the top and reaches the statue's left shoulder and left ear. Music and a male choir's wordless sounds enhance the drama. Jason carefully works his way across the forehead to the other side. Standing on the right eyebrow, he looks down and over at the hand with the Fleece. Then he jumps. He lands on the palm next to the Fleece, which he lifts into the air in triumph (Fig. 5).

Freda now cuts to Iolcus, to the Argo, and again to Iolcus, where the villain's machinations develop apace. Freda skips Jason's return to the Argo. In his defense we 


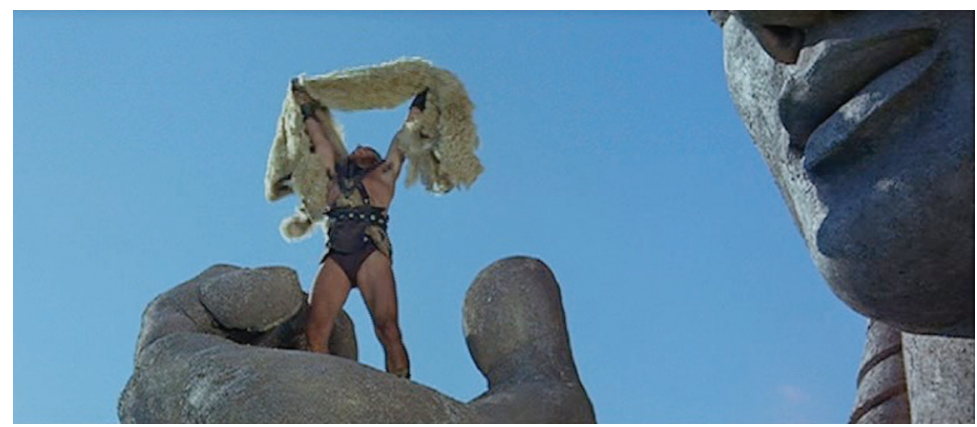

Fig. 5

could say that ending the kouros-and-Fleece sequence as he does provides a memorable climax, although a jump by Jason into the pool below would have been thrilling. But it might have been technically difficult or impossible, and a wet Fleece would not have looked good. So Freda hastens the conclusion of his film. The Argo is suddenly back home, the bad guy is killed in a fight, and we hear that "a new era of happiness" can begin. A priest announces that Thessaly is again "under the protection of the sacred Golden Fleece, a prodigious sign of the omnipotence of great Zeus." The final shot is of the god's statue. This is appropriate but a bit of a letdown after the much more impressive kouros we saw before.

A credit for animation at the film's beginning lists, by last name only, Carlo Rambaldi, the future specialeffects and creature wizard. Rambaldi was to receive numerous awards, including three Oscars, during his career. The alien in E.T. the Extra-Terrestrial (1982) is probably his best-known creation. Rambaldi had begun by creating, without screen credit, the dragon in Sigfrido (The Dragon's Blood, 1957). There followed a Minotaur in Teseo contro il minotauro (The Minotaur, 1960), make-up effects for Cottafavi's La vendetta

\section{archai圈}

no 22, Jan.-Apr. 2018

Martin M. Winkler, 'Apollonius and the Golden Fleece: A neomythological screen legacy', p. 319-362 


\section{archai圈}

no 22, Jan.-Apr. 2018

Martin M. Winkler, 'Apollonius and the Golden Fleece: A neomythological screen legacy', p. 319-362 di Ercole (Goliath and the Dragon, 1960), a strange Medusa for Perseo l'invincibile (Perseus Against the Monsters or even Medusa Against the Son of Hercules, 1963), and special effects in the Polyphemus episode of the six-hour Odissea (1968). We will encounter Rambaldi again below.

\section{Jason and the Argonauts (1963)}

The best-known film of the Argonaut myth came in 1963. Don Chaffey directed a British-American production from a screenplay co-written by playwright and librettist Beverley Cross. It was filmed on attractive Mediterranean locations and had a remarkable score by Bernard Herrmann. But its greatest asset are its fantasy creatures designed and animated by Ray Harryhausen: the Harpies, the bronze giant Talos, the dragon guarding the Golden Fleece, and the skeleton warriors sown from the dragon's teeth. This dragon, modeled on the Hydra of Greek myth, is the most magnificent monster ever to grace a screen version of the Argonauts' tale. Harryhausen perfected a process of stop-motion animation ("Dynamation"), in which minute movements of miniature creatures are photographed with a still camera and then projected sequentially to create the illusion of movement. ${ }^{12}$

The film emphasizes the importance of the Fleece from the beginning. In the first scene Pelias, about to make war on Thessaly and take the throne, receives a prophecy from a priest who is really Hermes in disguise. "I see a great tree at the end of the world," Hermes tells Pelias. "And in its branches hang the skull and skin of a ram. They gleam and shine, for it is a prize of the gods. A golden fleece." Twenty years 
after this, Jason encounters Pelias without realizing who he is; he tells him that he will take his rightful throne from the usurper and return Thessaly to its former state of glory and happiness. "But people need more than a leader," Jason continues. "They feel deserted by the gods. They need a miracle." Jason already knows about the Fleece. Pelias tells him: "They say it's a gift of the gods." Jason on his own proposes to get the Fleece for the good of his kingdom:

It has the power to heal, bring peace, and rid the land of famine. If I could bring it to Thessaly, it would inspire the people and wipe out the years of misrule. My land will be as rich as it was before Pelias murdered my father.

This is an appropriate, if neo-mythological, introduction to viewers of a sacred object with which many may not have been familiar. Jason's words inform them about the Fleece's supernatural qualities, not least its closeness to the gods, and raises their expectations to see it with their own eyes.

It is, however, not Jason but Pelias' son Acastus, one of the Argonauts, who first finds the Fleece. It is hanging from its tree in a dark and sinister-looking grove. Acastus is Jason's enemy and a saboteur; he attempts to pre-empt Jason and get the Fleece himself. Chaffey first shows the Fleece from Acastus' point of view in a long shot that turns into a medium close-up. The Fleece is large but not huge and has a magnificent golden sheen (Fig. 6). Its horns are elaborately curved (Fig. 7). This appearance justifies the verbal build-up the Fleece has received. As Acastus moves toward it, Chaffey cuts to the Argo. No dragon has ever been

\section{archai圈}

no 22, Jan.-Apr. 2018

Martin M. Winkler, 'Apollonius and the Golden Fleece: A neomythological screen legacy', p. 319-362 


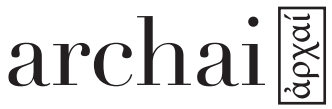

no 22, Jan.-Apr. 2018

Martin M. Winkler, 'Apollonius and the Golden Fleece: A neomythological screen legacy', p. 319-362

\section{6}

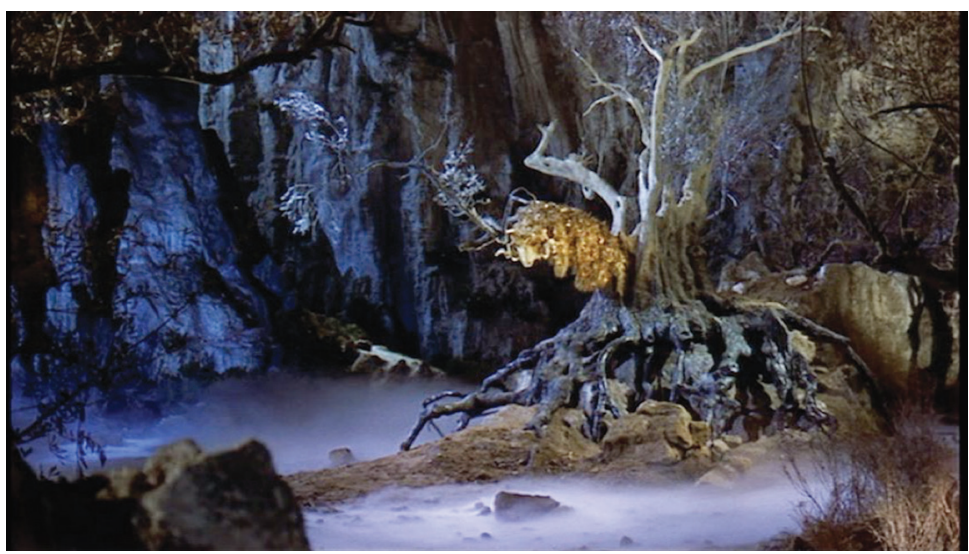

Fig. 6

mentioned, so Acastus does not expect any danger. Neither do viewers unfamiliar with the myth. The Fleece is there simply for the taking, it seems.

When Jason appears in the same spot a while later, everything is tranquil. The Fleece is hanging in the tree exactly as before. Jason, sword drawn, cautiously approaches; mysterious music on the soundtrack makes for a suspenseful atmosphere. Jason looks around, sticks his sword into the ground, and reaches up to the Fleece. A hissing sound from off-screen makes him turn around in close-up. Several Hydra heads are writhing before his face, also in close-up. Viewers are just as shocked as Jason is. When the Hydra approaches, we learn about Acastus' fate. The Hydra is holding him suspended in the coils of its tail and deposits him on the ground. Then it attacks. Jason's fight with the monster takes almost three minutes of screen time. He kills it by stabbing it in the neck and chest without help from Medea, who has come upon the scene a little earlier. The Hydra collapses below the tree. During the 


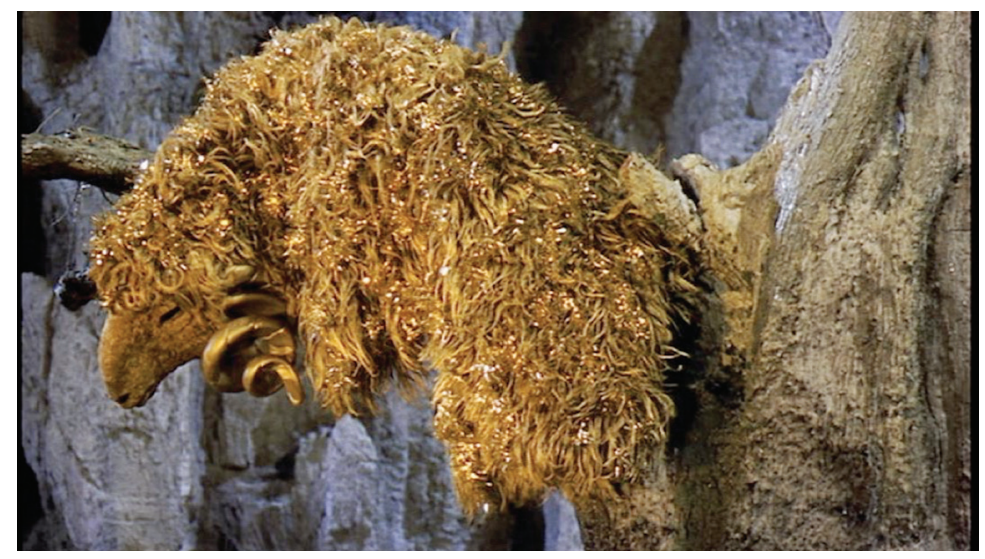

Fig. 7

fight the Fleece receives a short close-up, in which we see its fur gleaming and glittering. This is a clever reminder of the great prize for which Jason has undertaken this deadly fight and his entire voyage.

Acastus, dying, confesses his treachery; then some of the Argonauts and the Colchian warriors, led by Aeëtes, arrive. Jason commands Argus, his helmsman: "Get the Fleece!" Now comes a memorable visual twist on the myth. As soon as Argus touches the Fleece, its luster vanishes. The golden beauty turns into a drab grey (Fig. 8). Now the Fleece is just an old pelt. The divine object seems to have been defiled when touched by human hands. This contradicts what we have heard and seen so far. Jason's journey had been sanctioned and protected by the gods, especially by Hera, who had told him to get the Fleece. But perhaps we should not think about such an inconsistency too deeply. The emotional impact on us of the Fleece's unexpected transformation is worth any loss in logic. It is a magic moment, which exists for its visual sake alone. It also

\section{archai圈}

no 22, Jan.-Apr. 2018

Martin M. Winkler, Apollonius and the Golden Fleece: A neomythological screen legacy', p. 319-362 


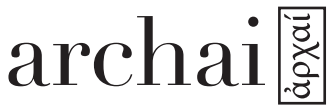

no 22, Jan.-Apr. 2018

Martin M. Winkler, 'Apollonius and the Golden Fleece: A neomythological screen legacy', p. 319-362

\section{8

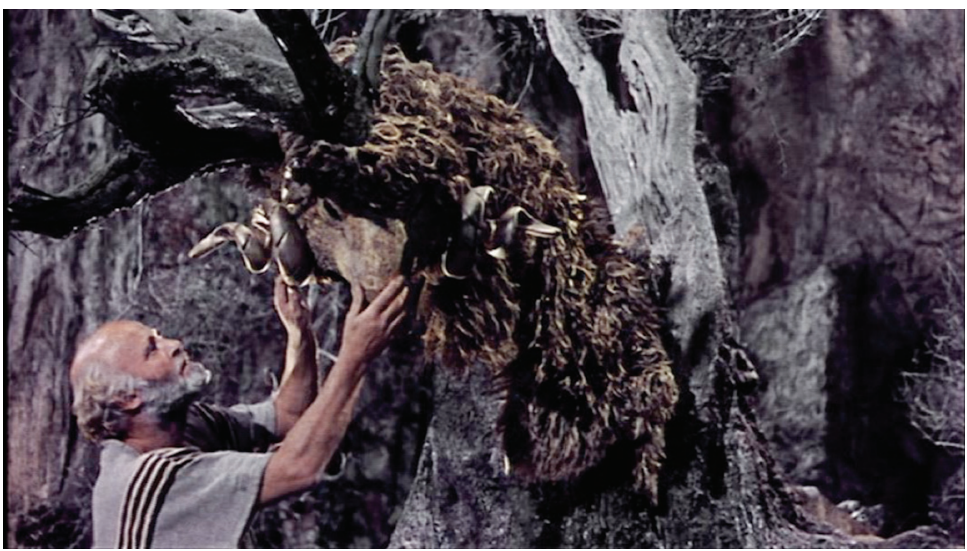

Fig. 8

echoes, no doubt unintentionally, one aspect of the version of the myth given by Valerius Flaccus. There it was not the Fleece but the tree, which it had illuminated, that went dark: "the tree at that moment... /...groans in pain and chagrin / as a gloom, deep and uncanny, descends to settle around it." ${ }^{13}$ This is both realistic about the darkness that results when a light source is being removed, and it is highly mythic: the animistic tree has emotions and utters them. The dark is also a foreshadowing of later events.

\section{Jason and the Argonauts (2000) And Percy JACKSON: SEA OF MONSTERS (2014)}

The American television film Jason and the Argonauts, directed by Nick Willing, takes us to a new phase in the adaptations of our myth, that of computer-generated images (CGI). Willing's version premiered within two days of the release of Ridley Scott's Gladiator, which gave a new lease on life to the ancient world on the big screen. Gladiator for 
the first time presented what could never have been shown before: a cyber-Rome. Special effects now began to predominate in historical and mythical epics. The time of painstaking handiwork like Harryhausen's was largely over. Exceptions were only to prove the rule.

Willing's film, partially indebted to Chaffey's, reflects its era in various ways, through feminism (an Amazon-type called Atalanta), multiculturalism (Orpheus is played by a black actor), and graphic on-screen violence. (A minor glitch is the mispronunciation of Iolcus as "Eye-óclus.") Pelias is a sadist, played by Dennis Hopper, an actor famous for his portrayals of psychopaths. Willing and his screenwriters incorporated material from Apollodorus, as may be seen by Jason's mother's name: Polymede rather than Apollonius' Alcimede. ${ }^{14}$ More importantly for us, the film demonstrates the two-sided nature of CGI filmmaking, its advantages and disadvantages. The Argonauts' discovery of the Golden Fleece is a case in point. But why have they traveled to Colchis?

Jason's tutor is the centaur Chiron, created with the help of CGI. He informs Jason about Pelias' murder of Aeson and the fate of his mother, who was forced to marry Pelias. An old lady whom Jason helps across a river tells him more about Pelias. His villainy goes so far as to squeeze his country dry for taxes because "searching for the Golden Fleece is an expensive business." The Fleece is "the greatest gift from gods to man," the woman, who is really Hera, continues, "craved by Pelias beyond all reason. He believes it will grant him his heart's desire."

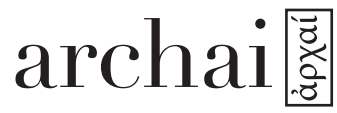

no 22, Jan.-Apr. 2018

Martin M. Winkler, 'Apollonius and the Golden Fleece: A neomythological screen legacy', p. 319-362 


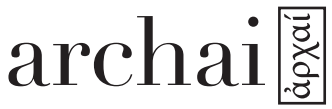

no 22, Jan.-Apr. 2018

Martin M. Winkler, 'Apollonius and the Golden Fleece: A neomythological screen legacy', p. 319-362
Pelias has already sent at least one expedition after the Fleece. His people, he tells his son who is eager to lead the next trip, are not clear about "the great benefits the Fleece will bestow upon them." Confronting Pelias, Jason offers to find the Fleece for him: "I can find it because I have protection of the gods." This suits Pelias just fine. He offers Jason the throne after his own death and a ship. But he threatens Jason with his mother's death if he does not return in time: "Your mother for the Fleece." Polymede warns Jason that Pelias will kill him even if he delivers the Fleece to him, which is "his obsession." She, too, calls it "his heart's desire." Then she reveals what that desire is: "Immortality. Eternal release from his doom so he may reign forever." This is quite a twist on the common versions of the tale. To Pindar, who called it imperishable, the Fleece is an "object of immortal life." ${ }^{15}$ But it does not bestow eternal life on others.

In Colchis, a few of the Argonauts and Medea hasten to the Fleece across a desert plain surrounded by high mountains. The Fleece's first appearance is impressive, although it is not quite clear from whose point of view Willing is showing it. In an extreme long shot that moves closer and closer although not into a close-up, we see the broken-off trunk and roots of a large dead tree. A deep canyon is visible immediately behind it. The Fleece is hanging high in the air, draped over a branch that is disproportionately thin for its position on the trunk. The Fleece appears small from a distance, but its color is strong enough to draw the viewer's eyes (Fig. 9). The Fleece is again swaying gently. Willing cuts back to the Argonauts, who observe it with wonder, and back to the Fleece. Suddenly the ground 


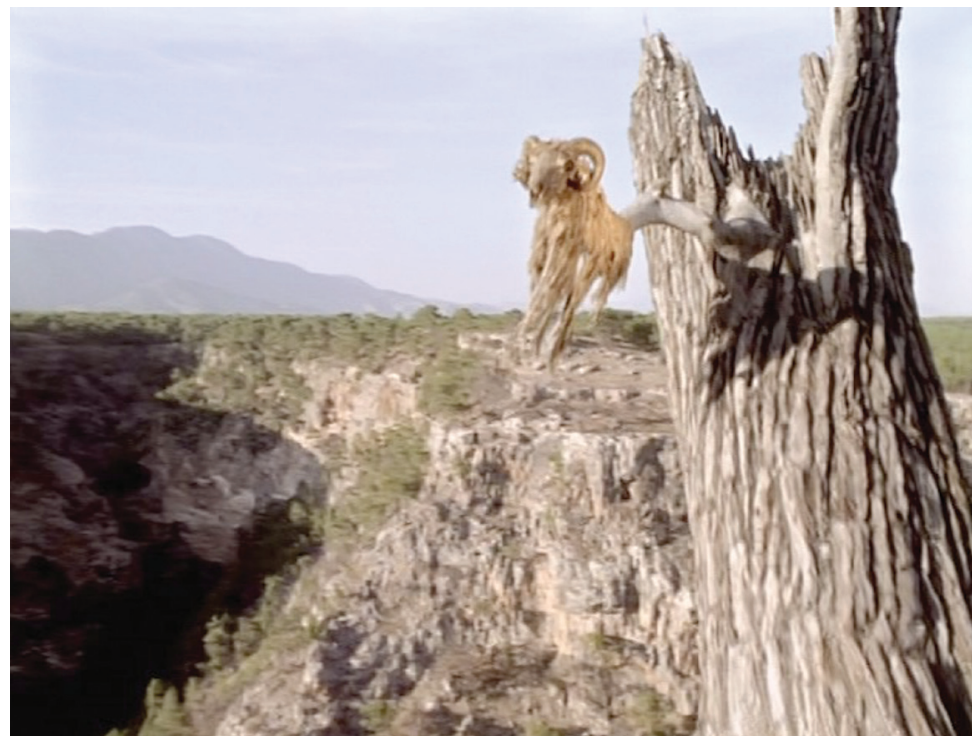

Fig. 9

begins to shake, and the gigantic head of a horned dragon rises from an abyss behind the tree, climbs up on the plateau, and menaces the Argonauts. In long shot it looks much less ferocious than it should. It appears to have been designed on the model of some prehistoric dinosaur and looks disappointingly artificial. We know immediately that it comes straight from a computer. Seen closer, of course, it is terrifying. Its tail strikes one of the Argonauts, who is climbing up the tree to reach the dragon's back. At this moment Willing inserts an attractive view of the Fleece (Fig. 10). Orpheus' lyre distracts and calms the beast, which has just snapped up one of the men. Jason ties one end of a rope to the tree. A string on Orpheus' lyre breaks and ends the spell of his music. In the ensuing melee Jason lures the dragon toward the abyss. It loses its balance and falls to its death; Jason saves himself with the rope. He climbs up the

\section{archai圈}

no 22, Jan.-Apr. 2018

Martin M. Winkler, 'Apollonius and the Golden Fleece: A neomythological screen legacy', p. 319-362 


\section{archai圈}

no 22, Jan.-Apr. 2018

Martin M. Winkler, 'Apollonius and the Golden Fleece: A neomythological screen legacy', p. 319-362

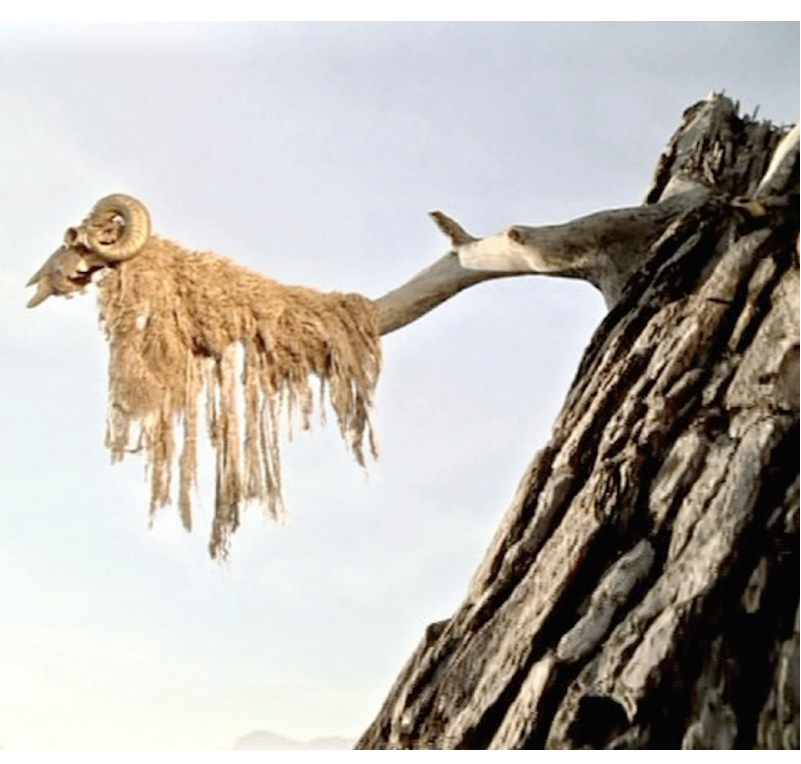

Fig. 10

tree for the Fleece, which he raises into the air as Freda's Jason had done. The Argonauts and Medea cheer.

On the return journey, Pelias' son steals the Fleece and wears it the way Heracles wears his lion's skin. "I've sailed with Jason and gained the Fleece," Acastus tells his father, who is next seen clutching it to his chest as if he were a child holding a favorite toy. Pelias commands his men to kill Jason and all the Argonauts. Soon he is wearing the Fleece as if he were Heracles (Fig. 11). Then he becomes interested in $\mathrm{Me}-$ dea's healing powers. She tricks him into bathing in a pool into which she pours her magic blood-red liquid. "You must bathe in these waters", she explains to Pelias. "The waters will release the power of the Fleece. Then once more you will be young. You will rule forever." That may not sound convincing to us, least of all 


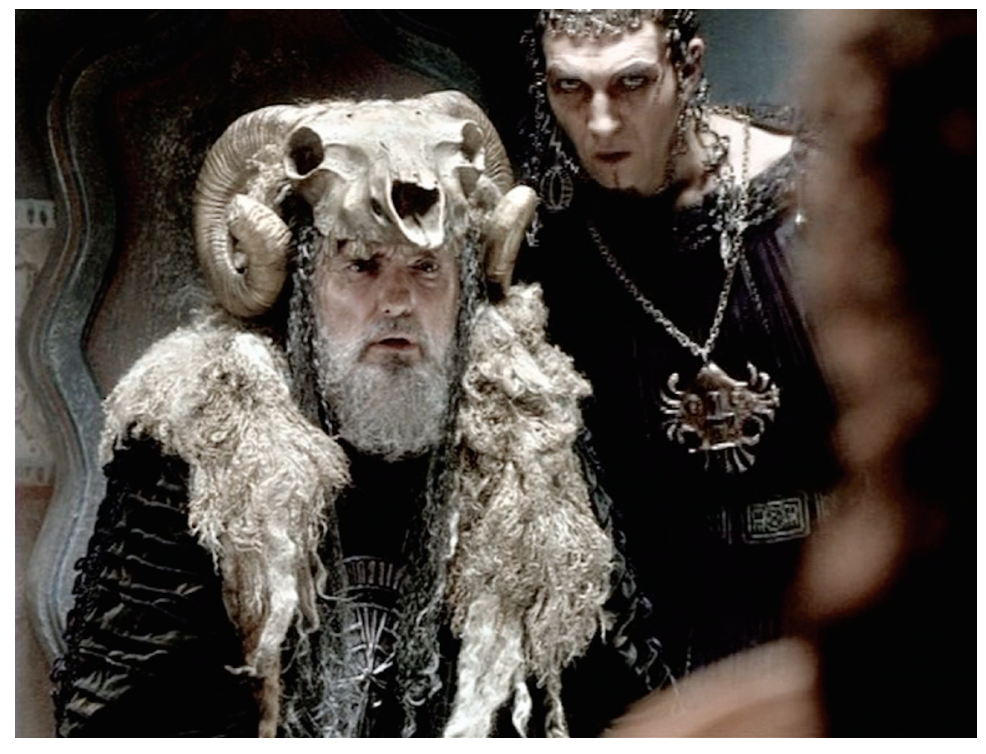

Fig. 11

if we know the myth, but it does to Pelias, who is obsessed with the Fleece and with his immortality. But it does not come to that. When Jason and his men fight their way into the palace, Pelias holds a sword to Medea's throat. "I see you wear the Fleece, uncle," says Jason. "Has it brought you your heart's desire? Has its power revived you? Made you immortal?" The villain unexpectedly falters. "Do I look like an immortal?" he almost whines. "The Fleece has no power," Jason tells him, "except that imagined by those who seek it. We make our own destiny, by our own actions." After a little more of this life lesson, Pelias relinquishes Medea and hands the Fleece over to Jason: "do with it what you will." Jason simply drops it to the ground. Pelias treacherously attempts to knife his nephew but dies on his own blade. "My destiny is to rule," Jason says before Pelias falls into the pool. Jason and Medea marry. They inspire even Zeus and Hera, the bickering couple on Olympus,

\section{archai 圈}

no 22, Jan.-Apr. 2018

Martin M. Winkler, 'Apollonius and the Golden Fleece: A neomythological screen legacy', p. 319-362 


\section{archai圈}

no 22, Jan.-Apr. 2018

Martin M. Winkler, 'Apollonius and the Golden Fleece: A neomythological screen legacy', p. 319-362 to be reconciled to each other with a kiss. A happy ending on earth as it is in heaven. And all thanks to the Fleece.

The next version to be discussed may be the most neo-mythological of all, for it transports ancient myth in time, to the twenty-first century, and place, to the United States. Percy Jackson, a boy-next-door type of teenager, is the hero of a series of bestselling young-adult novels by Rick Riordan. Percy turns out to be the son of Poseidon and encounters gods, demigods, creatures, and monsters while saving the Olympians from doom and destruction. In the second novel, Sea of Monsters, he and his small group of intrepid friends go on a quest for the Golden Fleece. The novel was filmed in 2013. German special-effects expert Thor Freudenthal directed.

Percy receives a prophecy that the Fleece is crucial to preserve Mt. Olympus and the gods. The Fleece is being kept in the Sea of Monsters, commonly known as the Bermuda Triangle. Its current owner is the giant Cyclops Polyphemus, who lives in a cave on Circe's island deep in that sea. There is a specific reference to Odysseus, although this Polyphemus is not blind. He contrasts with the human-sized Cyclops in Percy's company, a nice teenage boy. The Fleece's touch, we are informed, "can heal every person and every thing." The film's villain needs it to resurrect the Titan Kronos, who then will destroy the Olympians and reinstate himself as ruler of the world. Percy and Co. succeed in thwarting this dastardly scheme in the nick of time. At the end the Fleece is draped over the roots of a tree that used to be a teenage girl, a daughter of Zeus. She had been killed at the beginning, but Zeus pre-empted her death by changing her into a tree, an echo of the Philemon and Baucis myth. 


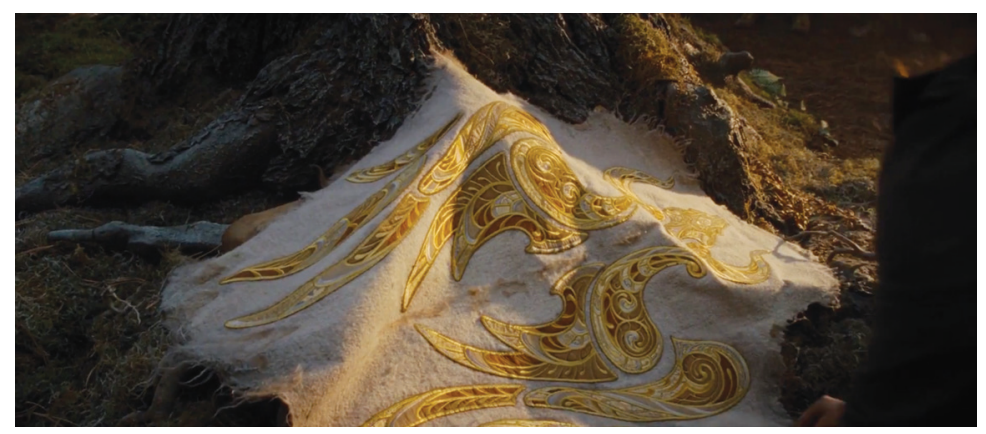

Fig. 12

The girl is now resurrected. All credit goes to the Fleece: "It was even more powerful than we thought." The Fleece is first shown in a painting that has been called up on a hand-held device-via Google, presumably. Its actual appearances are disappointing because we barely get to see it. Only at the end does it receive a full close-up. This Fleece is white and has non-figurative golden decorations (Fig. 12). It compares unfavorably with those in earlier films, especially the 1963 Jason and the Argonauts.

\section{Film Technology and the Supernatural}

Harryhausen's intriguing miniatures, animated by hand, strongly contrast with the computer-generated creatures in Percy Jackson: Sea of Monsters. Freudenthal's digital monsters are more dangerouslooking than Harryhausen's; they are also louder and faster. They look hyper-realistic but move realistically. This realism diminishes, perhaps even undermines, our sense of wonder and awe. Since we know that even with all their sound and fury they could never kill off the heroes of the tales in which they appear, their menace is significantly lessened.

\section{archai圈}

n 22, Jan.-Apr. 2018

Martin M. Winkler, Apollonius and the Golden Fleece: A neomythological screen legacy', p. 319-362 


\section{archai圈}

no 22, Jan.-Apr. 2018
Harryhausen was fully aware of this phenomenon and its implications. About myth and cinema he observed:

Fantasy in art and literature is as old as mythology itself. Film fantasy, being a more recent form of expression, has the added excitement of utilizing a flowing image and being in a state of constant motion; of combining sight, sound and imagination. No other medium of expression can project the complications of the imaginative, the wondrous or the bizarre as well as the motion picture. (HARRYHAUSEN, 1981, p. 127)

This fully applies to the myth of the Argonauts, which is chock-full of the wondrous and the bizarre. Concerning the two opposed ways of creating bizarre wonders on screen, Harryhausen concluded:

for all the wonderful achievements of the computer, the process creates creatures that are too realistic and for me that makes them unreal because they have lost one vital element-a dream quality. Fantasy, for me, is realizing strange beings...removed from the 21 st century...[and] creatures from the mind....Stop-motion supplies the perfect breath of life for them, offering a look of pure fantasy because their movements are beyond anything we know....The way the creatures moved [back then] encouraged a sense that one was watching a miracle, but when the miraculous becomes commonplace, the concept of miracles ceases to be miraculous. (HARRYHAUSEN and DALTON, 2003/2004, p. 8 and 282)

Carlo Rambaldi would make the same case later: 
Any kid with a computer can reproduce the special effects seen in today's movies. The mystery's gone. The curiosity that viewers once felt when they saw special effects has disappeared. It's as if a magician had revealed all of his tricks....There's no question that these computer films are well packaged but the charm has disappeared...The secret of creating what technology is unable to express lies in the work of the artisan, who is able to develop characteristics that touch our deepest emotions. ${ }^{16}$

A comparison of the old and the new Jason and the Argonauts fully bears out Harryhausen and Rambaldi. It may be telling that in Willing's film there is no bronze giant Talos, whose heroic death in Chaffey's film has become a mini-epic in its own right and surpasses Apollonius' version. ${ }^{17}$ We may reasonably suspect that Willing and his CGI technicians were smart enough to realize that they could not match the intensity of Talos' agony, despite the fact that he is a monster and a deadly threat to the Argonauts. That Talos is made of bronze and cannot alter his facial expression but, in Harryhausen's art, does express his suffering in such a way that viewers even feel sorry for him is extraordinary. Willing instead has Jason subdue a giant bronze bull-not two, as in the myth-with which to plow the field. This bull looks impressive at first but soon becomes monotonous. Freudenthal gives his teen heroes an even bigger and more ferocious bovine monstrosity to fight, one that has a second jaw inside its toothy big maw. Film buffs may think of the monster in Ridley Scott's Alien (1984). Here the smaller maw has three rotating drills that make us think of oil-well explorations. ${ }^{18}$ Willing's and Freudenthal's bull monsters are huge, noisy, fast, and ferocious. Like Willing's dragon, they are not very smart. Harryhausen's Talos was huge,

\section{archai圈}

no 22, Jan.-Apr. 2018

Martin M. Winkler, 'Apollonius and the Golden Fleece: A neomythological screen legacy', p. 319-362 


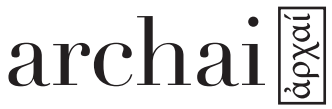

no 22, Jan.-Apr. 2018

Martin M. Winkler, 'Apollonius and the Golden Fleece: A neomythological screen legacy', p. 319-362

\section{8}

too. But he was silent except for the eerie creaking of his bronze joints, calm, slow but deliberate in his movements, which thus became more menacing, and resourceful. He was humanized because human sympathy and understanding created him, not a machine. (Harryhausen's detailed account, with illustrations, in Harryhausen and Dalton, 2003/2004, p. 156-159, is revealing in this regard.)

My quotations from Harryhausen and Rambaldi may not pertain directly to the different film presentations of the Golden Fleece, but they are worth considering in our context because they relate, centrally, to everything that surrounds the Fleece and permeates the aura in which it functions, both visually and in the manner in which we are, or are not, gripped by that aura. Riccardo Freda was very clear about this aspect. In the context quoted above he went on to say: "The secret of cinema is the gradual discovery of décor, of the world that surrounds the characters" (Lourcelles and Mizrahi, 1963, p. 20). Vittorio Cottafavi was equally emphatic: "Décor is a fundamental part of a film's dramatic structure. It contributes no less to a film than the actors" (Mourlet and Agde, 1961, p. 14). These statements apply to our subject. Harryhausen's creatures provide the perfect context for a Fleece that is more beautiful, more magical, and more mysterious than all those examined so far.

There remain, however, two memorable presentations of the Fleece that were created by significantly different cinematic minds. Art films are often highly idiosyncratic. The personalities of our final films' creators determined their works' style and content. Art cinema is auteur cinema. (Literature on this aspect 
of cinema is immense. A short overview in connection with classical literature and culture is in Winkler, 2009, p. 34-50.)

\section{MEDEA (1969)}

One of the greatest auteurs in film history is Pier Paolo Pasolini. He was not only a screenwriter, director, and occasional actor but also a poet, dramatist, novelist, essayist, translator, and painter. His work in cinema is another expression of his work as a poet. Pasolini developed the concept of the "cinema of poetry" (cinema di poesia; summarized at Winkler, 2009, p. 50-57). His Medea (1969), an adaptation of Euripides' tragedy, is a good illustration.

The Argonauts' voyage is the backstory to Euripides' play, but Pasolini made it an integral part of his film. As he had done with Oedipus Rex (1967) based on Sophocles, Pasolini retold the entire myth. Medea begins with a five-year-old Jason in the care of his tutor, the centaur Chiron. He teaches Jason about life, the nature of myth, and the origins of human culture. As part of his lessons Jason learns about Phrixus, Helle, and the Golden Fleece. It brought fortune to kings and guaranteed that their rule would not end. (Willing later made even more of this.) Chiron then tells Jason about Aeson and Pelias: "It's a complicated story."

Francisci and Chaffey had filmed their Colchian locations in Italy, while Freda stayed entirely in the studio. Willing shot his exteriors near Antalya on Turkey's Turquoise Coast. Pasolini outdid all of them. His Colchis was located at Göreme in Cappadocia, Turkey, now a

\section{archai圈}

no 22, Jan.-Apr. 2018

Martin M. Winkler, 'Apollonius and the Golden Fleece: A neomythological screen legacy', p. 319-362 


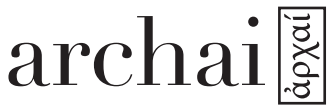

no 22, Jan.-Apr. 2018

Martin M. Winkler, 'Apollonius and the Golden Fleece: A neomythological screen legacy', p. 319-362

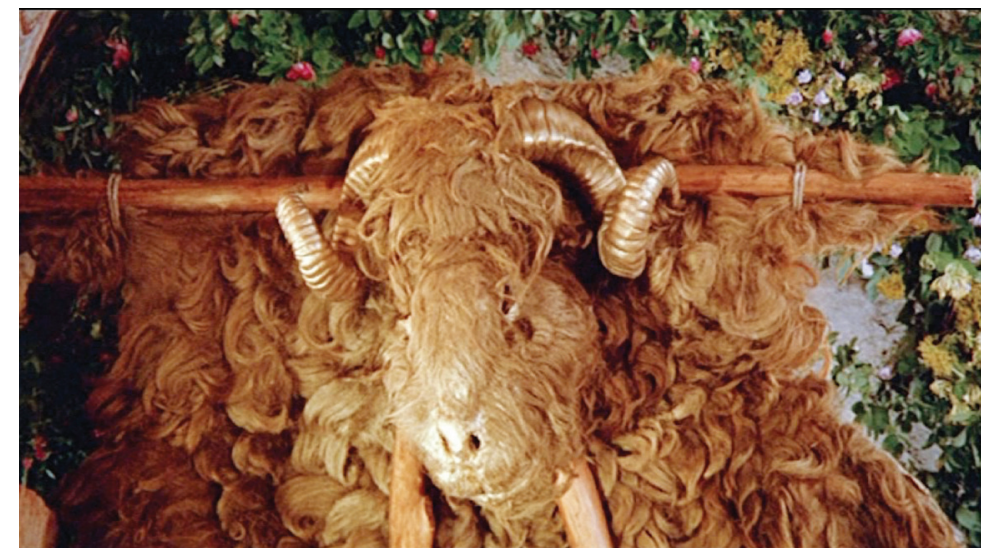

Fig. 13

World Heritage Site. It is striking for its rock formations, caves, and archaic Byzantine churches. This setting contrasts with the Italian locations that represent the city of Corinth, in which the tragedy of Medea unfolds. The opposition of nature and culture-the primeval rocks and caves of Colchis, Greece as seen in High Renaissance Italian architecture-could hardly be stronger. For Pasolini, the supposedly barbaric Colchians have a genuine civilization, whereas the Argonauts are a gang of ruffians mainly interested in loot. The exploitation of the Third World by First-World capitalism and colonialism underlies Pasolini's retelling of the myth.

Colchian religion is personified in Medea, princess and priestess. She visits the temple, cut deep into a rocky hill, in which the Golden Fleece is being worshipped. It is spread out on wooden beams (Fig. 13). Medea sees Jason entering but immediately withdrawing and collapses. Is this a vision? Then Medea looks at the Fleece pensively and, for a moment, smiles mysteriously. Expressive close-ups on her face 


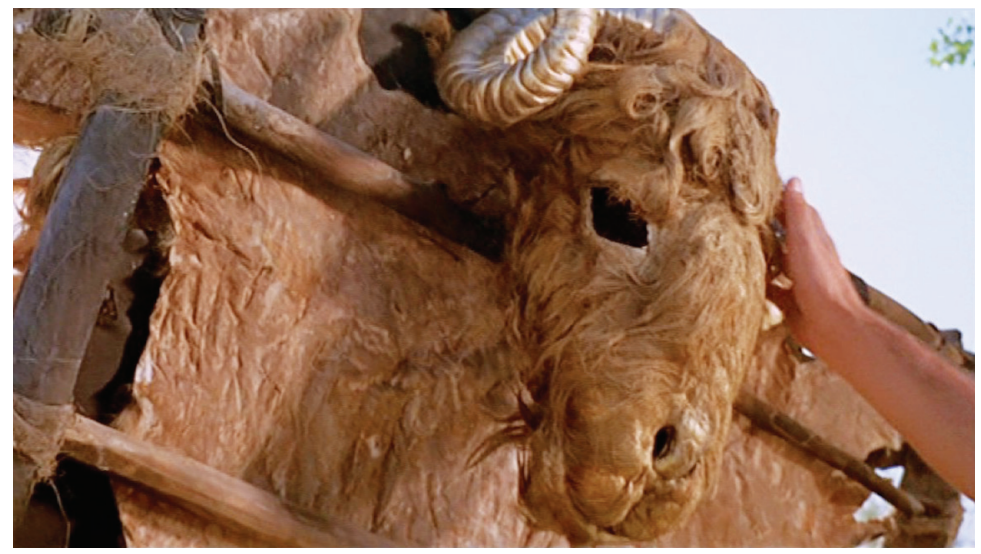

Fig. 14

tell us that she knows what is going to happen. Medea then shakes the Fleece as if to make sure that it is safely fastened. Or is she testing her strength to take it down? She leaves the temple after a long vigil. At home she rouses her brother Apsyrtus; both return to the temple. Apsyrtus removes the Fleece, and Medea delivers it to Jason. The great quester of myth is relieved of his task and of all danger; in the process he is stripped of all heroism. Dux femina facti. There is no guardian dragon, no Aeëtes to set up impossible tasks. When Jason's hand touches the Fleece in closeup, Pasolini makes it look much less beautiful than it appeared before, although its color remains the same. Its empty eye sockets, previously barely noticeable but now prominent, are clearly a bad omen (Fig. 14). They contrast with Medea's and Jason's eyes as they look at each other in close-ups across the Fleece. It unites them now but will eventually become the precondition for their ruin. Not one word has been exchanged between them. Back in Iolcus, the Fleece has lost all its sheen. Pelias matter-of-factly informs Jason that kings

\section{archai圈}

n²2, Jan.-Apr. 2018

Martin M. Winkler, 'Apollonius and the Golden Fleece: A neomythological screen legacy', p. 319-362 


\section{archai圈}

no 22, Jan.-Apr. 2018

Martin M. Winkler, 'Apollonius and the Golden Fleece: A neomythological screen legacy', p. 319-362

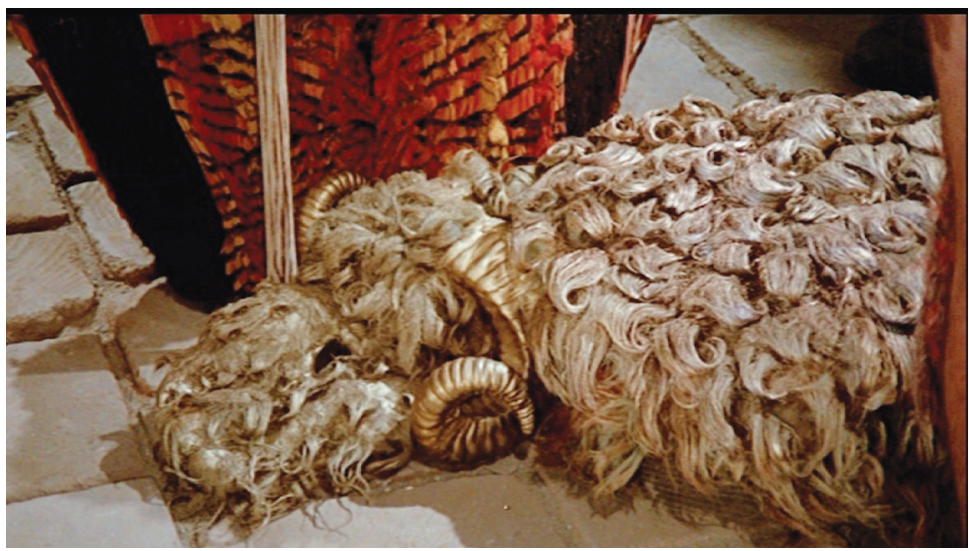

Fig. 15

are not obliged to keep their promises and that he has no intention to hand over his kingdom. Jason stays calm. Almost contemptuously, he drops the Fleece on the floor. A final close-up on it reinforces Pasolini's cultural criticism: still golden but no more than an old animal skin (Fig. 15). Jason tells Pelias: "Look there. Take your fleece, the sign of the perpetuity of power and of order! My undertaking has at least served me to realize that the world is greater than your kingdom." Going well beyond Chiron's earlier words, Jason adds what his own experiences have taught him: "that ram's pelt, far away from your country, has no meaning at all any more." He leaves with Medea.

Shortly after, Jason sees Chiron again, who is now both a centaur and a human. Chiron tells Jason about Medea's "spiritual catastrophe," her disorientation: that of "an ancient woman [donna antica] in a world that does not know the one in which she has always believed." Medea had helped Jason in Colchis; in Greece she is forced to abandon her origins and 
beliefs. After coming from Pelias' palace, Medea is stripped of her elaborate native garment and dressed in Greek clothes. Symbolically, Medea's fate is comparable to what happens with the Fleece: far away from where either belongs, existence has no meaning any more. In Iolcus Medea's appearance, like that of the Fleece, loses its luster.

Soon Jason and Medea are in Corinth. It is now years later, and Medea's life has acquired new meaning when she becomes a wife and mother. But this does not last. Medea finds a new connection to her Colchian identity, and tragedy ensues. In retrospect it becomes clear why Pasolini chose to include the backstory to Euripides' play in his adaptation. The importance of the Fleece for his version of Medea's story is profound. The Fleece is granted a deeper meaning in this than in any other film.

\section{The Golden Thing (1971)}

A notably different art film is this German version by four directors. Edgar Reitz, best known today for his epic three-part series Heimat (1984, 1992, 2004), collaborated with Alf Brustellin, Ula Stöckl, a pioneer of feminist filmmaking, and Greek Nicos Perakis. Stöckl and Reitz wrote the script; Reitz also handled the cinematography. The English title of their film does not quite capture the tone of irony that the original implies: Das goldene Ding is better rendered "That Golden Thing" or "That Thing of Gold." Since this is the least known of all versions, I translate some of the relevant statements about it that Stöckl has published on her Internet site. She observes:

\section{archai葶}

no 22, Jan.-Apr. 2018

Martin M. Winkler, 'Apollonius and the Golden Fleece: A neomythological screen legacy', p. 319-362 


\section{archai圈}

no 22, Jan.-Apr. 2018

Martin M. Winkler, 'Apollonius and the Golden Fleece: A neomythological screen legacy', p. 319-362
The film takes place at a time when humans were still children (and the children humans) and everybody wanted only one thing: the golden thing. Eleven-year-old Jason, and with him Heracles, Castor and Pollux, Orpheus and other sons of Greek kings go on a treasure hunt on the Argo, their ship.... In contrast to the myth as transmitted, here the Argonauts do not overcome dangers through their heroic courage or help from the gods but through reason. The divine powers can be explained logically, and the Argonauts reach their goal because they put their scientifically trained minds to use and leave nothing to the gods. ${ }^{19}$

This is quite astonishing, not only as a rationalizing approach to myth and its supernatural elements but also as a practical application of an ancient concept: that in the age of myth mankind was in its infancy, which it eventually outgrew through greater understanding of the world. This knowledge came with the development from mythos to logos, as the title of a classic study on the subject put it. ${ }^{20}$ So the Argonauts and Medea are all played by children. Stöckl reports that the four directors carried out prodigious amounts of research:

We pored over whole libraries, chiefly relying on sources in J. J. Bachofen's Mother Right, Hermann Fränkel's Noten zu den Argonautika des Apollonios, and Apollonios himself. They confirmed our assumption that most of the ancient heroes must, in fact, have been children. The majority of them had put their chief heroic deeds behind them at age 15,16 ; Theseus, for example, who does not appear in our film, killed the Minotaur when he was 15 .

The filmmakers' research is certainly admirable, but their conclusion about the Greek heroes' age is not 
supported by either Fränkel or Apollonius. To ancient Greeks and Romans, the Argonauts were not children but adults. Pindar, for example, specifically gives Jason's age as twenty (Pyth. 4. 104). Is then The Golden Thing a misbegotten undertaking, a labor of love doomed to failure from the start? Not at all. Once our initial surprise or disbelief has worn off, we can, and do, take the young actors as seriously as we would adults. This is by no means a kiddie movie. As Stöckl has put it:

the team of filmmakers...were concerned in presenting to television viewers and filmgoers the ancient Greek Argonaut myth in such a way that they can readily understand it and also feel entertained....This intention is already expressed in the title, which popularizes the legendary Golden Fleece in the land of Colchis as a "thing." Still, the filmmakers did not want to lower the myth to the level of pop culture or a cartoon, nor did they want to flatten it out; rather, and after intensive study of sources, they wanted to make it readily understandable, suspenseful, and demystified according to recently gained insights.

What then do the directors do with Apollonius and the myth? Their Aeson has previously failed at bringing the Golden Thing from Colchis and now wants to get another expedition under way. The reason is that the gold of Colchis will make everybody in Iolcus rich and happy. The key to all this gold, we will learn later, is the Fleece. But Aeson realizes that a conventional ship cannot get through the Clashing Rocks. So he proposes to Argos to build "the fastest and most beautiful ship in the world." Science-minded Jason shows them what kind of ship to build. Then Pelias launches a coup d'état. Jason decides to sail and calls for all young

\section{archai圈}

n 22, Jan.-Apr. 2018

Martin M. Winkler, 'Apollonius and the Golden Fleece: A neomythological screen legacy', p. 319-362 


\section{archai圈}

no 22, Jan.-Apr. 2018

Martin M. Winkler, 'Apollonius and the Golden Fleece: A neomythological screen legacy', p. 319-362

\section{6}

princes to join him. The voyage of the Argo, filmed on locations on the Traunsee in Austria, takes up most of the film's running time.

In Colchis Jason boasts to Aeëtes that a large number of Greek kings have arrived to get the Golden Thing. Aeëtes is unfazed and tells Jason that, if only he has the courage, he could get it on his own. Aeëtes also summons Medea and announces that Jason will fight against his Invincibles, the film's substitute for the sown warriors in the myth. The Invincibles are monstrous fighting machines worked by slaves from a large subterranean cave. In keeping with the filmmakers' rationalistic approach, there is no dragon. Medea, who has been warned against helping Jason, nevertheless gives him some necessary information about the Invincibles. Jason asks her what the Golden Thing is. "An animal skin," Medea says. "It is as valuable as all the treasures in the world." While Jason defeats the Invincibles, Medea fetches the Golden Fleece from its subterranean hiding place in the temple of Hecate and joins the Argonauts on their flight from Colchis. She does not, of course, kill her brother Apsyrtus; instead, the two have a tender farewell scene.

Together with the Argonauts, we get a first good look at the Fleece when it is on board the Argo. Its outside is of pure white color, and it looks just like what it is: a real fleece. "Is that it?" asks one of the Argonauts. Medea turns the Fleece over and holds it up for all to see. Its underside is of a realistic brown color. A large map of the ancient world is drawn on it, with its bodies of water painted in gleaming gold and its rivers in black (Fig. 16). The Argonauts gaze at it, 


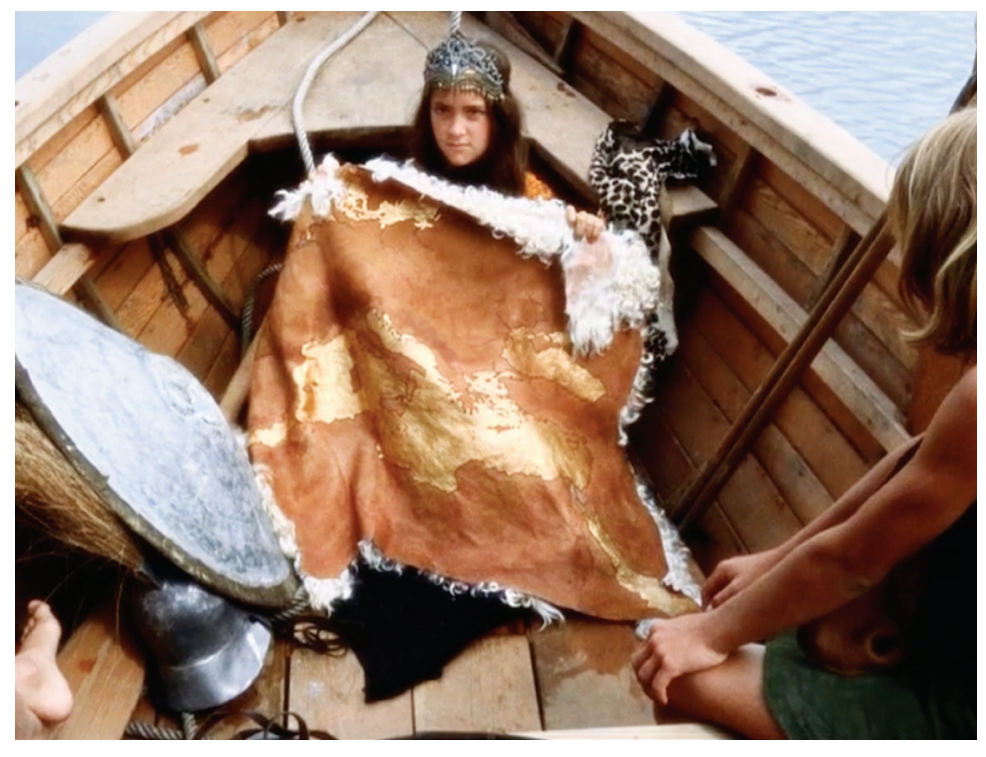

Fig. 16

and their point of view becomes ours when the camera, in a slowly traveling close-up, moves across the map. Its gold is now partly in the sunlight and partly in shadow. The sight is extremely beautiful. Red dots on the map, Medea explains, represent treasures. We see these in a tighter close-up. "Good luck, kings!" says Medea and holds the Fleece higher. The image freezes, the end credits roll, and the screen slowly fades to black.

The ending could not be more moving. It is highly poetic, not least because Medea's innocent wish has a deeper resonance for viewers who know what is in store for Jason and herself than it has for either of them at this moment. The Golden Thing thus turns out to be more than just a thing. The Golden Thing is not entirely in the spirit of Apollonius or other classical authors, but it fully delivers what the directors wanted to achieve. Spectators may be entertained as much as they were

\section{archai圈}

no 22, Jan.-Apr. 2018

Martin M. Winkler, 'Apollonius and the Golden Fleece: A neomythological screen legacy', p. 319-362 


\section{archai圈}

no 22, Jan.-Apr. 2018 intended to be and may even understand the myth better, but more than all that they are moved, perhaps much more than they were intended to be.

\section{CodA}

The different films' approaches to representations of the Argonaut myth in general and of the Golden Fleece in particular provide us with a pleasing range of meanings that are expressed or implied in their stories and in their images. As director Freda once put the matter: "The image must be a continual surprise to the eye" (Lourcelles and Mizrahi, 1963, p. 20). A film, we understand, should be a thauma idesthai. Freda was probably unaware of how close he was to the first and greatest epic poet of ancient Greece. In a few our films the Fleece itself is a golden wonder: khryseion thauma idesthai.

\section{Notes}

1 On ancient images of the Fleece see Neils, 1990, especially p. 632-634 (sections $\mathrm{H}-\mathrm{K}$ and $\mathrm{N}$ on Jason, the dragon, and the Fleece), and the illustrations at 5. 2, p. 424-433, especially plates $32,36-38$, and 42 (in black and white). See further Schefold and Jung, 1989, p. 15-18 on Phrixus and the ram and 30-33 on Jason and the Fleece.

2 Apollon. Argon. 4. 120 and 124-126. Quoted from Green, 2007, p. 154.

3 Apollon. Argon. 4. 170-178; the quotations from 172-173, 176, and 177-178 are at Green, 2007, p. 155.

4 Apollon. Argon. 4. 184-185; Green, 2007, p. 156.

5 Apollon. Argon. 4. 1142 and 1145-1146; Green, 2007, p. 181. 
6 Pind. Pyth. 4. 161, 230-231, and 241. The quotations are from Nisetich, 1980, p. 182 and 185-186. At Pyth. 4. 68 Pindar calls the Fleece "wholly golden." So does Eur. Med. 5.

7 Val. Flacc. Argon. 8. 114-116, with rutila pellis at 114. The quotation is from Slavitt, 1999, p. 155.

8 Green, 2007, p. 299 (on Argon. 4. 173-177). Braswell, 1988, p. 317-318 (on Pind. Pyth. 4. 231), provides further details about the Fleece, with source references.

9 Mourlet and Agde, 1961, p. 24. Leprohon, 1972, p. 174179, discusses Cottafavi and his term. See further Elley, 1984, p. 13-24 (chapter titled "Epic into Film").

10 Images here and throughout are screenshots and appear in compliance with fair-use rules of international copyright regulations.

11 Quoted, in my translation, from Lourcelles and Mizrahi, 1963, 20.

12 Detailed information about the art of Harryhausen's animation appears in Harryhausen and Dalton, 2003/2004, 2005/2006, and 2008. I have examined Jason and the Argonauts in Winkler, 2007, p. 458-463. Harryhausen had made the animation short The Story of King Midas in 1953, but with a medieval setting. He returned to Greek myth with the 1981 version of Clash of the Titans, written by Cross.

13 Val. Flacc. Argon. 8. 119-120; Slavitt, 1999, p. 155. At Ov. Met. 7. 151, the dragon is "guardian of the golden tree" (custos... arboris aureae). This striking expression draws attention to the Fleece's shining splendor but should not be understood as implying that the tree had turned golden. Rather, the adjective is a transferred epithet: from what the tree holds to the tree itself.

14 Apollod., Library of Mythology 1. 9.16; Apollon. Argon. 1. 233. Apollodorus summarizes the myths of Jason, Medea, and the Argonauts at 1.9. 16-28.

15 The quotation is from Segal, 1986, p. 112. Segal then speaks about "the immortality-conferring quality of the fleece" in regard to the fame of Battus, ancestor of the ode's recipient.

\section{archai圈}

n 22, Jan.-Apr. 2018

Martin M. Winkler, 'Apollonius and the Golden Fleece: A neomythological screen legacy', p. 319-362 


\section{archai圈}

no 22, Jan.-Apr. 2018

Martin M. Winkler, 'Apollonius and the Golden Fleece: A neomythological screen legacy', p. 319-362

\section{0}

16 Quoted from Rambaldi's 2012 obituary notice in The Telegraph; http://www.telegraph.co.uk/news/obituaries/9590601/ Carlo-Rambaldi.html.

17 I give a brief appreciation of this sequence in Winkler, 2007, p. 462-463.

18 The three drills are probably not an echo, albeit vague, of the dragon with triple tongue and hooked teeth that guards the Golden Fleece in Ov. Met. 7. 149-151.

19 Source: http://www.ula-stoeckl.com/Film-Seiten/06 Das_Goldene_Ding.html. The next two quotations are taken from this page as well.

20 Nestle, 1940. For recent contributions to the subject see, e.g., Buxton, 1999; Hawes, 2014.

\section{BIBLIOGRAPHY}

BOYLE, A. J. (2014) (ed. tr. comm.). Seneca: Medea. Oxford, Oxford University Press.

BRASWELL, B. K. (1988). A Commentary on the Fourth Pythian Ode of Pindar. Berlin, De Gruyter.

BUXTON, R. (1999) (ed.). From Myth to Reason? Studies in the Development of Greek Thought. Oxford, Oxford University Press, rpt. 2001.

ELLEY, D. (1984). The Epic Film: Myth and History. London, Routledge \& Kegan Paul.

FRÄNKEL, H. (1968). Noten zu den Argonautika des Apollonios. Munich, Beck.

GREEN, P. (2007) (tr. and comm.). Argonautika by Apollonios Rhodios. Expanded ed. Berkeley, University of California Press. 
HARRYHAUSEN, R. (1981). Film Fantasy Scrapbook. 3rd ed. London, Tantivy Press/San Diego: Barnes.

HARRYHAUSEN, R.; T. DALTON (2003/2004). Ray Harryhausen: An Animated Life. London: Aurum Press/New York, Billboard Books.

HARRYHAUSEN, R.; T. DALTON (2005/2006). The Art of Ray Harryhausen. London, Aurum Press/ New York, Billboard Books.

HARRYHAUSEN, R.; T. DALTON (2008). A Century of Stop Motion Animation: From Méliès to Aardman. London, Aurum Press/New York: Billboard Books.

HAWES, G. (2014). Rationalizing Myth in Antiquity. Oxford, Oxford University Press, 2014. https:// doi.org/10.1093/acprof:oso/9780199672776.001.0001

HUNTER, R. (2015) (ed. and comm.). Apollonius of Rhodes: Argonautica Book IV. Cambridge, Cambridge University Press.

LEPROHON, P. (1972). The Italian Cinema. Tr. R. Greaves and O. Stallybrass. New York, Praeger.

LOURCELLES, J.; S. MIZRAHI (1963). Entretien avec Riccardo Freda. Présence du cinéma 17, p. 11-30.

MOURLET, M.; P. AGDE (1961). Entretien avec Vittorio Cottafavi. Présence du cinéma 9, p. 5-28.

NEILS, J. (1990). Iason. Lexicon Iconographicum Mythologiae Classicae, 5.1, p. 629-638.

\section{archai圈}

n 22, Jan.-Apr. 2018

Martin M. Winkler, Apollonius and the Golden Fleece: A neomythological screen legacy', p. 319-362 


\section{archai圈}

no 22, Jan.-Apr. 2018

Martin M. Winkler, 'Apollonius and the Golden Fleece: A neomythological screen legacy', p. 319-362
NESTLE, W. (1940). Vom Mythos zum Logos: Die Selbstentfaltung des griechischen Denkens von Homer bis auf die Sophistik und Sokrates. Stuttgart, Kröner. 2nd ed. 1942; several rpts.

NISETICH, F. (1980) (tr.). Pindar's Victory Songs. Baltimore, Johns Hopkins University Press.

SCHEFOLD, K.; F. JUNG (1989). Die Sagen von den Argonauten, von Theben und Troia in der klassischen und hellenistischen Kunst. Munich, Hirmer.

SEGAL, C. (1986). Pindar's Mythmaking: The Fourth Pythian Ode. Princeton, Princeton University Press.

SLAVITT, D. R. (1999) (tr.). The Voyage of the Argo. Baltimore, Johns Hopkins University Press.

WINKLER, M. M. (2007). Greek Myth on the Screen. In WOODARD, R. D. (ed.). The Cambridge Companion to Greek Mythology. Cambridge: Cambridge University Press, p. 453-479. https://doi. org/10.1017/CCOL9780521845205.018

WINKLER, M. M. (2009). Cinema and Classical Texts: Apollo's New Light. Cambridge, Cambridge University Press; rpt. 2012. https://doi.org/10.1017/ CBO9780511575723

Submitted in June and accepted for publication in August, 2016 